\title{
EVALUATION TYPES OF EXTERIOR WALLS TO RECONSTRUCT IRAN EARTHQUAKE AREAS (AHAR HERIS VARZEQAN) BY USING AHP AND FUZZY METHODS
}

\author{
Seyed Teimor HOSSEINI a , Shahin LALE AREFI b, Mahdi BITARAFAN c, \\ Sajjad ABAZARLOU d, Edmundas Kazimieras ZAVADSKAS e,* \\ ${ }^{a}$ Department of Strategic Management, University of Doa, Tehran, Iran \\ ${ }^{b}$ Department of Civil Engineering, University of Mohaghegh Ardabili, P.O. Box 56199-11397, Ardabil, \\ Iran \\ ${ }^{c}$ Department of Civil Engineering, Research Institute of Shakhes Pajouh, P.O. Box 81655-1537, Isfahan, \\ Iran \\ ${ }^{d}$ Department of Urban and Design Planning, Islamic Azad University Central Tehran Branch, Tehran, \\ Iran \\ e Research Institute of Smart Building Technologies, Vilnius Gediminas Technical University, Sau- \\ letekio al. 11, LT-10223 Vilnius, Lithuania
}

Received 27 July 2015; accepted 31 December 2015

\begin{abstract}
Two earthquakes of magnitude $6.1 \mathrm{mb}$ occurred at the Ahar and around 16000 residential buildings were destroyed. One of the conspicuous issues in the earthquake is property management to reconstruct and confront the crisis. In this regard, since the most damage inflicted on the buildings occurs in the exterior walls, therefore, the most financial resources must be spent on reconstructing this part of damaged buildings. Thus, this paper was conducted in order to reduce expenditure and increase the resistance of the walls. The urban fabric of the area didn't sustain much damage and only the exterior walls of the buildings were collapsed. Thus, the main aim of this article is to study different types of exterior walls for renewal and reconstruction of buildings in earthquake area. To approach this aim, using group decision-making method. This paper presents the comparison of FUZZY and AHP. In this regard, this research is centralized on types of exterior walls to reconstruct Iran earthquake areas (Ahar, Heris, Varzeqan). Five main methods have been chosen by asking experts in the related fields and to evaluate and select the best of exterior walls. Finally 3D panel wall was selected as the optimal wall for reconstruction of earthquake area.
\end{abstract}

KEYWORDS: Earthquake; Reconstruct; Exterior wall; Fuzzy, AHP

\section{INTRODUCTION}

On $11^{\text {th }}$ August 2012 two big earthquakes of magnitude $6.1 \mathrm{mb}$ occurred at $20 \mathrm{~km}$ from west of Ahar and $28 \mathrm{~km}$ from north-west of Ahar, leaving at least 306 people dead, 2600 injured and around 16000 residential buildings were destroyed (EarthquakeReport.com 2012). Right after the earthquake dozen of organizations and national groups were mobilized, tens of search and rescue teams were dispatched to the zone and the biggest rescue operation after Bam earthquake was performed. This area includes two fabrics: urban and rural. Urban fabric includes buildings constructed by concrete,

\footnotetext{
* Corresponding author. E-mail: edmundas.zavadskas@vgtu.lt
}

steel and masonry structure and the rural fabric has got many masonry and adobe buildings.

The urban fabric of the area didn't sustain much damage and only the exterior walls of the steel and concrete buildings were collapsed and the structure of the buildings remained intact. It should be mentioned that in urban fabric buildings using glass in the façade were destroyed. The rural fabric sustained significant damage in the earthquake due to lack of proper structure to bear earthquake force. There for the main aim of this research is studying all types of exterior walls to renew and reconstruct of damaged buildings in earthquake area, Ahar Heris and Varzeqan. Some of the researches about types of exterior walls are presented in this article. 
Azari-N et al. (2012) investigated how change of mullion materials would affect the health and environmental impacts associated with a typical confidence-weighted (CW) system over its life cycle. Results indicate that $\mathrm{CW}$ system with glulam timber mullions causes the least and $\mathrm{CW}$ system with extruded aluminum mullions causes the most damage to the environment and human health over their life cycle.

Efstathiades et al. (2007) presented a method for structural health monitoring and fault detection in curtain-wall systems. They studied several models of a damaged curtain-wall system and the respective numerical simulation. Strengthening of masonry walls with the application of FRP strips improved the capacity and thus the ultimate wall capacity reached (Albert et al. 2001; Willis et al. 2009; Korany, Drysdale 2006). Some examples from important studies that cover the out of plane behavior of the masonry brick walls and results are summarized below.

Ehasani et al. (1999) and Ehsani et al. (1997) conducted an experimental study on three halfscale un-reinforced brick walls that are retrofitted with graphite (FRP) vertical composite strips. These walls tested under cyclic out-of-plane loading and results showed that the tested specimens are capable of supporting out-of-plane loads with the magnitude of up to 32 times the weight of the tested wall. The study concluded that the GFRP and FRP composite strips are both good for retrofitting. URM walls against lateral loads caused by seismic forces. Hamilton and Dolan (2001) performed a series of tests on unreinforced concrete masonry walls that are strengthened with FRP composites. The composites are attached to the tension side. The objective of their research work is aimed to develop general approaches and design guidelines for strengthening concrete masonry walls with FRP.

Triantafillou (1998) presented systematic numerical analysis procedures for predicting short term strength of masonry walls that are strengthened with externally bonded FRP laminates under monotonic out-of-plane bending, in-plane bending and in-plane shear and finally conducted that strengthening of masonry wall with externally bonded FRP laminates appears to be an effective method for retrofitting. In recent years a large number of books and articles have been published dealing with building failures. Some of the latest include: Del Coz Díaz et al. (2010), Tiago and Júlio (2010), Brencich (2010), Lee and Ishihara (2010), Sasaki et al. (2010), Folic and Zenunovic (2010), Kwon and Kim (2010), Calderón et al. (2009) and
Ivorra et al. (2009). Many authors have published case studies on masonry buildings in which the masonry itself was the load-bearing element. Of these, we could cite here Betti et al. (2010), Betti and Vignoli (2008a, 2008b), Ceci et al. (2009) and Lourenço et al. (2007). However, most of the studies related to failures in masonry structures have concentrated on historical buildings and very few of the recent publications have given their attention to modern buildings in which masonry has minimum load-bearing functions and is mostly used to close off spaces. One of the exceptions is the recent work of Fathy et al. (2009), who studied cracking in outside masonry walls mainly caused by deformation of the floor slabs. Numayr et al. (2012) studied the behavior of three-dimensional (3D) exterior walls when subjected to high velocity projectiles or bullets fired from a variety of firearms of different calibers. Results showed 3D exterior walls provide an acceptable level of protection from ammunition fired from commonly used firearms. Chai et al. (2015) studied the statistical modeling of the service life prediction of painted structure. But as seen in previous researches, majority of investigations have merely focused on behavior of on type of wall and have studied it as an index such as resistance against earthquake and explosion. But creative aspect of recent research is comparing all types of exterior walls in order to reconstruct damaged area, considering the important indices. In this paper for achieving this aim first all types of exterior walls in the earthquake area were studied, next the involved indices in selecting optimal wall for reconstruction were explored and at last, using AHP and Fuzzy method, the results of evaluation model performance were obtained.

\section{METHODOLOGY}

In this study all indices needed in appraisement of different exterior walls in order to reconstruct damaged buildings are derived by interviewing experts in related fields such as earthquake engineering, structure engineering and construction management (Table 1). After that 40 questionnaires were given to 40 experts to evaluate the efficient indices. By using group decision-making method, according to pairwise comparison pattern، existential necessity of each index, and also all types of exterior walls in the form of Likert scale (one to nine) was approached and finally the priorities and final weight was determined.

To study the validation of questionnaires Cronbach's alpha test has been used. 
Table 1. Background Information of experts

\begin{tabular}{llllll}
\hline Variable & Items & No & Variable & Items & No \\
\hline 1) Earthquake & Bachelor & & 3) Structure & Bachelor & \\
engineer & Master & 5 & engineer & Master & 5 \\
& Ph.D. & 6 & & Ph.D. & 7 \\
2) Construction & Bachelor & & 4) Top & Bachelor & \\
management & Master & 4 & Manager & Master & 3 \\
& Ph.D. & 6 & & Ph.D. & 4 \\
\hline
\end{tabular}

\subsection{AHP method}

AHP method is developed by Saaty (1980) and its main point is how to determine the relative importance of a set of activities in a multi-criteria decision problem. According to this method, decision maker could incorporate and translate judgments on an intangible qualitative criterion alongside tangible quantitative criteria (Badri 2001). The AHP method is based on three steps: first, structure of the model; second, comparative judgment of the alternatives and the criteria; and third, the synthesis of the priorities (Dağdeviren 2008). The recent developments of decision making models based on AHP methods are: Chou et al. (2013) presented a new bidding strategy to support decisionmaking that is based on a combined framework of FAHP method and then analyze data on bridge construction projects that are taken from a database of the Taiwan Public Construction Commission. Kang et al. (2013) was to develop a risk management visualization system that can analyze the degrees of risks in construction projects using objective quantifying methodologies for gathering risk information using fuzzy and AHP techniques. Bagocius et al. (2014) determined sequence of construction of the offshore wind farm construction applying permutation method. Jato-Espino et al. (2014) applied a review of application of multicriteria decision making methods in construction especially AHP method. Šiožinytè et al. (2014) upgrading the old vernacular building to contemporary norms by multiple criteria approach. Gudiene et al. (2014) studied identification and evaluation of the critical success factors for construction projects in Lithuania by AHP approach. Keršulienè and Turskis (2014) using hybrid linguistic Fuzzy multiple criteria group in selection of a chief accounting officer. Kutut et al. (2014) Assessment of priority alternatives for preservation of historic buildings using model based on additive ratio assessment method (ARAS) and AHP methods. Shi et al. (2014) applied FAHP method in advance optimized classification and application of surround- ing rock based on fuzzy analytic hierarchy process and tunnel seismic prediction. Simanaviciene et al. (2014) assessing reliability of design, construction, and safety related decisions. Vodopivec et al. (2014) studied renovation priority ranking by multi-criteria assessment of architectural heritage. Sivilevicius and Maskeliunaite (2014) presented the numerical example for evaluating the criteria describing the quality of the trip by international train. Kildiene et al. (2014) applied complex assessment model for advanced technology deployment. Zavadskas et al. (2015) using AHP method in multi-criteria selection of a deep-water port in the Eastern Baltic Sea. Kriksciuniene et al. (2015) used by modified analytic hierarchy process model in project performance evaluation. Medineckiene et al. (2015) using ARAS and AHP methods in multi-criteria decision-making system for sustainable building assessment/certification.

In the first step, a sophisticated decision problem is structured as a hierarchy. This method breaks down a sophisticated decision making problem into the hierarchy of objectives, criteria, and alternatives.

These decision elements make a hierarchy of structure in such a way that the goal of the problem is at the top point of the hierarchy, and criteria is in the middle and all the alternatives are at the bottom.

In the second step, some comparisons of the alternatives and criteria are done. In AHP, comparisons are happened based on a standard nine point scale (Table 2).

Table 2. Nine-point intensity of importance scale and its description

\begin{tabular}{ll}
\hline Definition & Intensity of importance \\
\hline Equally important & 1 \\
Moderately more important & 3 \\
Strongly more important & 5 \\
Very strongly more important & 7 \\
Extremely more important & 9 \\
Intermediate values & $2,4,6,8$ \\
\hline
\end{tabular}


Let $C=\left\{C_{j} \mid j=1,2, \ldots, n\right\}$ be the set of criteria. The result of the pair wise comparison on $n$ criteria can be summarized in an $(n \times n)$ evaluation matrix $A$ in which every element $a_{i j}(i, j=1,2, \ldots, n)$ is the quotient of weights of the criteria, as shown in Eq. 1:

$$
A=\left[\begin{array}{cccc}
a_{11} & a_{12} & \ldots & a_{1 n} \\
a_{21} & a_{22} & \ldots & a_{2 n} \\
\vdots & \vdots & \ddots & \vdots \\
a_{n 1} & a_{n 2} & \ldots & a_{n n}
\end{array}\right], a_{i i}=1, a_{j i}=1 / a_{i j}, a_{i j} \neq 0 \text {. }
$$

At the third step, the mathematical process commences to normalize and find the relative weights for each matrix. The relative weights are given by the right eigenvector $(w)$ corresponding to the largest eigenvalue $\left(\lambda_{\max }\right.$, as:

$$
A w=\lambda_{\text {max }} w .
$$

If the pair wise comparisons are completely consistent, the matrix $A$ has a rank of 1 and $\lambda_{\max }=n$.

In this case, weights can be obtained by normalizing any of the rows or columns of $A$ (Wang, Yang 2007). The quality of the AHP output is strictly related to the consistency of the pair wise comparison judgments (Dağdeviren 2008). The consistency is defined by the relation between the entries of $A$ : $a_{i j} \times a_{j k}=a_{i k}$. The consistency index (CI) is:

$$
\mathrm{CI}=\left(\lambda_{\max }-n\right) /(\mathrm{n}-1) \text {. }
$$

as it is presented in Eq. 4 The final consistency ratio (CR), using which one can conclude whether the evaluations are sufficiently consistent, is calculated as the ratio of $\mathrm{CI}$ and the random index (RI):

$$
\mathrm{CR}=\mathrm{CI} / \mathrm{RI} \text {. }
$$

The CR index should be lower than 0.10 to accept the AHP results as consistent (Wang, Yang 2007). If the final consistency ratio exceeds this value, the evaluation process has to be repeated to improve consistency (Dağdeviren 2008). The CR index could be used to calculate the consistency of decision makers as well as the consistency of all the hierarchy (Işıklar, Büyüközkan 2007).

\subsection{FUZZY method}

Fuzzy set (FS) theory is a generalization of conventional set theory and was introduced by Zadeh in 1965 and 1972. It provides a mathematical tool for dealing with linguistic variables associated with natural languages.

Descriptions of these topics can be found in several texts (Zadeh 1972, 1973; Bellman, Zadeh 1977). A central notion of fuzzy set theory, as described in the following sections, is that it is permissible for elements to be only partial elements of a set rather than full membership.

Figure 1 shows the flowchart of fuzzy inference system. The development of Fuzzy logic (FL) was motivated by the need for a conceptual framework which can address the issue of uncertainty and lexical imprecision. Some of the essential characteristics of FL relate to the following (Kaufmann, Gupta 1991; Robert 1995):

In FL, exact reasoning is viewed as a limiting case of approximate reasoning.

In FL, everything is a matter of degree.

In FL, knowledge is interpreted as a collection of elastic or, equivalently, fuzzy constraint on a collection of variables.

Inference is viewed as a process of propagation of elastic constraints.

Any logical system can be fuzzified. There are two main characteristics of fuzzy systems that give them better performance for specific applications:

- Fuzzy systems are suitable for uncertain or approximate reasoning, especially for the system with a mathematical model that is difficult to derive.

- FL allows decision making with estimated values under incomplete or uncertain information.

Zadeh stated that the attempts to automate various types of activities from assembling hardware to medical diagnosis have been impeded by the gap between the way human beings reason and the way computers are programmed.

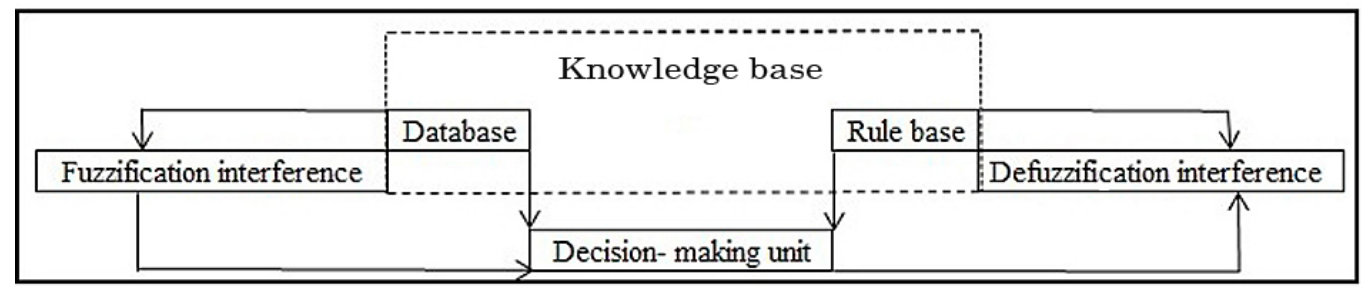

Fig. 1. Flow diagram of fuzzy inference system 
FL uses graded statements rather than ones that are strictly true or false. It attempts to incorporate the "rule of thumb" approach generally used by human beings for decision making. Thus, FL provides an approximate but effective way of describing the behavior of systems that are not easy to describe precisely (Dubois, Prade 1980).

FL controllers, for example, are extensions of the common ESs that use production rules like "if-then" statements. With fuzzy controllers, however, linguistic variables like "tall" and "very tall" might be incorporated in a traditional ES. The result is that FL can be used in controllers that are capable of making intelligent control decisions in sometimes volatile and rapidly changing problem environments. FL techniques have been successfully applied in a number of applications like, computer vision, decision making and system design including ANN training. The most extensive use of FL is in the area of control, where examples include controllers for cement kilns, braking systems, elevators, washing machines, hot water heaters, air-conditioners, video cameras, rice cookers and photocopiers (Lakhmi, Martin 1998). The recent developments of fuzzy methods are: Akadiri et al. (2013) using fuzzy methods in evaluation model for the selection of sustainable materials for building projects. Batayneh et al. (2013) studied intelligent fuzzy based tracking controller for a dual-axis solar PV system. Li et al. (2013) used a fuzzy approach in evaluating stakeholder satisfaction during public participation in major infrastructure and construction projects. Nassar and Hosny (2013) fuzzy clustering validity for contractor performance evaluation Yazdani-Chamzini et al. (2013). Developing a fuzzy model based on subtractive clustering for road header performance prediction. YazdaniChamzini (2014a) applied an integrated fuzzy multi criteria group decision making model for handling equipment selection. Yazdani-Chamzini (2014b) proposing a new methodology based on fuzzy logic for tunneling risk assessment. Yazdani-Chamzini et al. (2014) proposing a new methodology for prioritising the investment strategies in the private sector of Iran. Kaya and Kahraman (2014) studied comparison of fuzzy multicriteria decision making methods for intelligent building assessment. Esmaeili et al. (2014) using SWOT, and FUZZY MCDM methods the formulation of organization strategies thought integration of freeman model.

\section{CASE STUDY}

Azerbaican block is well-known for its long history of disastrous earthquake activity and the effects are observable since Precambrian geology period. This part of Iran is the joint of two mains orogeny: Alborz and Zagros. These two zones are extremely earthquake prone; as a result Azerbaican block owns a special seismology structure.

Comparing geodetic and seismological paleontology and dispersal pattern of active transformations in this zone indicates very high earthquake potential in the area.

This area includes two fabrics: urban and rural. Urban fabric includes buildings constructed by concrete, steel and masonry structure and the rural fabric has got many masonry and adobe buildings. The urban fabric of the area didn't sustain much damage and only the exterior walls of the steel and concrete buildings were collapsed and the structure of the buildings remained intact. One of the most important reasons of people injury in this earthquake was debris of exterior walls constructed of steel or concrete (Fig. 2).

\section{EXTERIOR WALLS OF THE EARTHQUAKE AREA}

\section{Brick walls (A1)}

Brick is known as one of the old and traditional materials used in construction of exterior walls. Today, in spite of modernization, it has retained its place. IN urban fabric of the earthquake area dozen of buildings were built with this kind of wall that unfortunately didn't behave properly against earthquake force as a result of inadequate attachment between wall and structure and inadequate resistance against seismic lateral loads. Brick wall debris can cause a huge damage to people and equipment.

\section{D panel wall (A2)}

Cancellation panels are made of 2 steel meshes with a polystyrene insulator placed between them. According to the fact that these prefabricated panels are built in the factory and then are carried to the place, they cost so much more than the other types of the walls.

3D panel has got a desired resistance against impact waves specially earthquake impact waves. Lightweight of the material makes debris removal operation much easier. According to the mentioned 
advantages, this wall is one of the bests in renewal of collapsed buildings.

\section{Cement block wall (A3)}

Cement blocks are manufactured in hollow and solid forms and are used in constructing exterior, interior (load-bearing and non-load-bearing) and retaining walls. Due to the fragility and hollowness of the blocks, these walls are not resistant enough against earthquake force. This type of wall is heavier than other types such as dry wall, clay block wall and $3 \mathrm{D}$ panel, there for it causes more debris. In earthquake areas, has been observed that buildings with this type of wall have collapsed and destroyed.

\section{Clay block wall (A4)}

This type of wall was mostly seen in the earthquake area. One of the main advantages of this wall is its light weight compared to brick walls. IN this system there's a desired debris removal potential as a result of light weight of material and existence of cavities. Due to fragility of the blocks of the wall it's not resistant enough against earthquake. Clay walls should be avoided in the earthquake prone areas.

\section{Curtain wall (A5)}

Curtain-wall systems are becoming one of the most important parts of modern structures, since they greatly improve both their serviceability and their appearance. This is due to the fact that curtain-wall systems recently began to be designed as a part of the principal load-bearing structure. In consequence, a wide research effort on the structural behavior of such facades is nowadays in progress having as final target the improvement of the response of such systems and the optimum design (from the financial and safety point of view) since in certain cases the cost of the facade exceeds the fifteen percent of the total cost of a structure (Efstathiades et al. 2003).
Curtain walls are not resistant against earthquake force because of low diameter and material specifications. Debris of the broken wall can cause many injuries to people and damages to the equipment. According to what mentioned, this system is the worst for using in earthquake prone areas.

\section{EFFECTIVE INDICES IN APPRAISEMENT OF EXTERIOR WALL}

These indices were determined by asking experts in related field. Decision-making indices include a set of economical and constructional specifications gathered in Table 3.

Table 3. Appraisement indices of all types of exterior walls

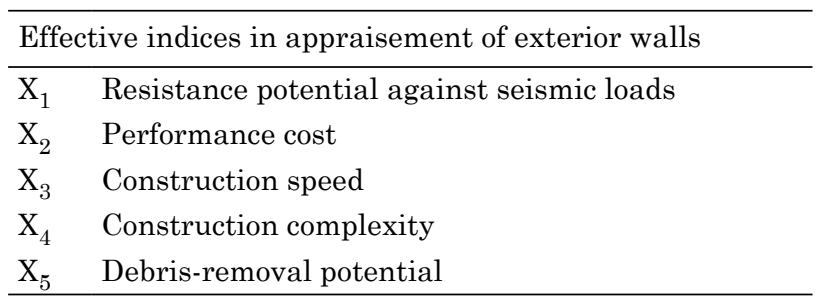

\section{RESULTS}

\section{AHP results}

In this stage using obtained weights from the mentioned questionnaire, the pairwise comparison judgment matrix of indices (Table 4) has been formed and then pairwise comparison judgment matrixes of each exterior walls has been extracted for each index which has been presented in the Table 4 .

In Table 4, the importance degrees of assessment indexes for evaluation of the exterior walls appraisement to reconstruct Iran earthquake areas (Ahar, Heris, Varzeqan) are compared. According to the results of the questionnaire, the index of resistance potential against seismic loads with the weight of 0.501 possesses the most weight and the construction speed index with the weight of
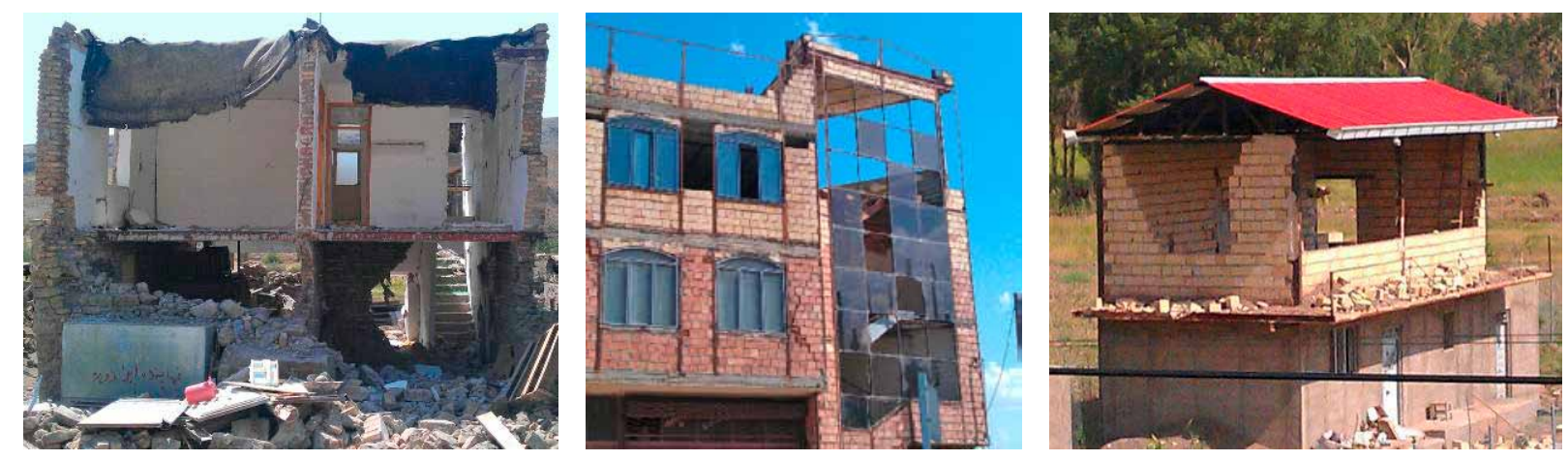

Fig. 2. An example of earthquake area destruction due to seismic loads 
0.216 has the second rank. Next indexes are performance cost, debris-removal potential and construction complexity with the weight of 0.134 , 0.088 and 0.061 respectively.

Table 4. Pairwise comparison judgment matrix of indices and criteria influencing the choice of exterior walls appraisement to reconstruct Iran earthquake areas (Ahar Heris Varzeqan)

\begin{tabular}{lllllll}
\hline & $\mathrm{X}_{1}$ & $\mathrm{X}_{2}$ & $\mathrm{X}_{3}$ & $\mathrm{X}_{4}$ & $\mathrm{X}_{5}$ & Weights \\
\hline $\mathrm{X}_{1}$ & 1 & 4.25 & 3.15 & 6.12 & 4.95 & 0.501 \\
$\mathrm{X}_{2}$ & & 1 & 0.45 & 2.42 & 2.13 & 0.134 \\
$\mathrm{X}_{3}$ & & & 1 & 3.12 & 2.76 & 0.216 \\
$\mathrm{X}_{4}$ & & & & 1 & 0.51 & 0.061 \\
$\mathrm{X}_{5}$ & & & & & 1 & 0.088 \\
\hline
\end{tabular}

$I R=0.01$

In this part, the paired judging matrix of each type of exterior walls is analyzed in terms of resistance potential against seismic loads. As the results show in the Table 5, the exterior walls are prioritized from first to fifth 3D panel wall weighted 0.658 , brick walls weighted 0.111 , cement block wall weighted 0.096 , clay block wall weighted 0.088 and finally curtain wall weighted 0.047 respectively.

Table 5. Pairwise comparison judgment matrix of each type of exterior walls in the index of resistance potential against seismic loads

\begin{tabular}{lllllll}
\hline & $\mathrm{A}_{1}$ & $\mathrm{~A}_{2}$ & $\mathrm{~A}_{3}$ & $\mathrm{~A}_{4}$ & $\mathrm{~A}_{5}$ & Weights \\
\hline $\mathrm{A}_{1}$ & 1 & 0.12 & 1.12 & 1.24 & 3.42 & 0.111 \\
$\mathrm{~A}_{2}$ & & 1 & 7.38 & 7.52 & 8.86 & 0.658 \\
$\mathrm{~A}_{3}$ & & & 1 & 1.23 & 2.12 & 0.096 \\
$\mathrm{~A}_{4}$ & & & & 1 & 2.21 & 0.088 \\
$\mathrm{~A}_{5}$ & & & & & 1 & 0.047 \\
\hline
\end{tabular}

$I R=0.02$.

In this part, the paired judging matrix of each type of exterior walls is analyzed in terms of performance cost. As the results show in the Table 6 , the exterior walls are prioritized from first to fifth, cement block wall weighted 0.393 , brick walls weighted 0.259 , clay block wall weighted 0.212 , curtain wall weighted 0.071 and finally $3 \mathrm{D}$ panel wall weighted 0.065 respectively.

Table 6. Pairwise comparison judgment matrix of each type of exterior walls in the index of performance cost

\begin{tabular}{lllllll}
\hline & $\mathrm{A}_{1}$ & $\mathrm{~A}_{2}$ & $\mathrm{~A}_{3}$ & $\mathrm{~A}_{4}$ & $\mathrm{~A}_{5}$ & Weights \\
\hline $\mathrm{A}_{1}$ & 1 & 4.25 & 0.45 & 1.52 & 4.02 & 0.259 \\
$\mathrm{~A}_{2}$ & & 1 & 0.18 & 0.32 & 0.90 & 0.065 \\
$\mathrm{~A}_{3}$ & & & 1 & 1.43 & 4.96 & 0.393 \\
$\mathrm{~A}_{4}$ & & & & 1 & 2.95 & 0.212 \\
$\mathrm{~A}_{5}$ & & & & & 1 & 0.071 \\
\hline
\end{tabular}

$I R=0.01$.
In this part, the paired judging matrix of each type of exterior walls is analyzed in terms of construction speed. As the results show in the Table 7, the exterior walls are prioritized from first to fifth, clay block wall weighted 0.408 , 3D panel wall weighted 0.222 , cement block wall weighted 0.187 , brick walls weighted 0.129 and finally curtain wall weighted 0.054 respectively.

Table 7. Pairwise comparison judgment matrix of each type of exterior walls in the index of construction speed

\begin{tabular}{lllllll}
\hline & $\mathrm{A}_{1}$ & $\mathrm{~A}_{2}$ & $\mathrm{~A}_{3}$ & $\mathrm{~A}_{4}$ & $\mathrm{~A}_{5}$ & Weights \\
\hline $\mathrm{A}_{1}$ & 1 & 0.44 & 0.88 & 0.31 & 2.53 & 0.129 \\
$\mathrm{~A}_{2}$ & & 1 & 1.21 & 0.41 & 4.13 & 0.222 \\
$\mathrm{~A}_{3}$ & & & 1 & 0.43 & 4.84 & 0.187 \\
$\mathrm{~A}_{4}$ & & & & 1 & 5.35 & 0.408 \\
$\mathrm{~A}_{5}$ & & & & & 1 & 0.054 \\
\hline
\end{tabular}

$I R=0.02$.

In this part, the paired judging matrix of each type of exterior walls is analyzed in terms of construction complexity. As the results show in the Table 8, the exterior walls are prioritized from first to fifth, 3D panel wall weighted 0.490 , clay block wall weighted 0.157 , cement block wall weighted 0.155 , brick walls weighted 0.151 and finally curtain wall weighted 0.047 respectively.

Table 8. Pairwise comparison judgment matrix of each type of exterior walls in the index of construction complexity

\begin{tabular}{lllllll}
\hline & $\mathrm{A}_{1}$ & $\mathrm{~A}_{2}$ & $\mathrm{~A}_{3}$ & $\mathrm{~A}_{4}$ & $\mathrm{~A}_{5}$ & Weights \\
\hline $\mathrm{A}_{1}$ & 1 & 0.31 & 0.87 & 0.83 & 4.24 & 0.151 \\
$\mathrm{~A}_{2}$ & & 1 & 3.95 & 3.57 & 7.12 & 0.490 \\
$\mathrm{~A}_{3}$ & & & 1 & 1.21 & 3.09 & 0.155 \\
$\mathrm{~A}_{4}$ & & & & 1 & 4.12 & 0.157 \\
$\mathrm{~A}_{5}$ & & & & & 1 & 0.047 \\
\hline
\end{tabular}

$I R=0.02$.

In this part, the paired judging matrix of each type of exterior walls is analyzed in terms of debris-removal potential. As the results show in the Table 9, the exterior walls are prioritized from first to fifth, 3D panel wall weighted 0.442 , clay block wall weighted 0.272 , cement block wall weighted 0.156 , brick walls weighted 0.085 and finally curtain wall weighted 0.044 respectively.

Table 9. Pairwise comparison judgment matrix of each type of exterior walls in the index of debris-removal potential

\begin{tabular}{lllllll}
\hline & $\mathrm{A}_{1}$ & $\mathrm{~A}_{2}$ & $\mathrm{~A}_{3}$ & $\mathrm{~A}_{4}$ & $\mathrm{~A}_{5}$ & Weights \\
\hline $\mathrm{A}_{1}$ & 1 & 0.19 & 0.44 & 0.32 & 2.43 & 0.085 \\
$\mathrm{~A}_{2}$ & & 1 & 3.21 & 1.95 & 7.44 & 0.442 \\
$\mathrm{~A}_{3}$ & & & 1 & 0.43 & 4.21 & 0.156 \\
$\mathrm{~A}_{4}$ & & & & 1 & 5.65 & 0.272 \\
$\mathrm{~A}_{5}$ & & & & & 1 & 0.044 \\
\hline IR= 0.02. & & & & &
\end{tabular}


Table 10. Final weight of each type of exterior walls

\begin{tabular}{|c|c|c|c|c|c|c|}
\hline \multirow[t]{2}{*}{ Importance coefficient } & \multirow[t]{2}{*}{ Criteria } & \multicolumn{5}{|c|}{ Scores from the experts' ideas } \\
\hline & & $\begin{array}{l}\text { Brick } \\
\text { walls }\end{array}$ & $\begin{array}{l}3 \mathrm{D} \text { panel } \\
\text { wall }\end{array}$ & $\begin{array}{l}\text { Cement } \\
\text { block wall }\end{array}$ & $\begin{array}{l}\text { Clay block } \\
\text { wall }\end{array}$ & $\begin{array}{l}\text { Curtain } \\
\text { wall }\end{array}$ \\
\hline Resistance potential against seismic loads & 0.501 & 0.111 & 0.658 & 0.096 & 0.088 & 0.047 \\
\hline $\begin{array}{l}\text { Resistance potential against seismic loads } \\
\times \text { average obtained scores }\end{array}$ & & 0.056 & 0.330 & 0.048 & 0.044 & 0.023 \\
\hline Performance cost & 0.134 & 0.259 & 0.065 & 0.393 & 0.212 & 0.071 \\
\hline Performance cost $\times$ average obtained scores & & 0.035 & 0.009 & 0.052 & 0.028 & 0.010 \\
\hline Construction speed & 0.216 & 0.129 & 0.222 & 0.187 & 0.408 & 0.054 \\
\hline Construction speed $\times$ average obtained scores & & 0.028 & 0.048 & 0.040 & 0.088 & 0.012 \\
\hline Construction complexity & 0.061 & 0.151 & 0.490 & 0.155 & 0.157 & 0.047 \\
\hline \multicolumn{2}{|l|}{ Construction complexity $\times$ average obtained scores } & 0.009 & 0.030 & 0.009 & 0.010 & 0.003 \\
\hline Debris-removal potential & 0.088 & 0.085 & 0.442 & 0.156 & 0.272 & 0.044 \\
\hline \multicolumn{2}{|l|}{ Debris-removal potential $\times$ average obtained scores } & 0.007 & 0.039 & 0.014 & 0.024 & 0.004 \\
\hline \multicolumn{2}{|l|}{ Final score of type of exterior walls } & 0.142 & 0.404 & 0.183 & 0.219 & 0.141 \\
\hline
\end{tabular}

In order to determine final weight of each type of exterior walls, Table 10 was used. In this table, indicators were written in horizontal rows with their weights. Then, final gained weights of indexes indicating importance coefficient of each index are multiplied by gained weights for each type of exterior walls and final value for each type of exterior walls is obtained from the total of products.

Finally, as shown in Table 10, the total rate of each type of exterior walls has been investigated regarding the selected parameters in which $3 \mathrm{D}$ panel wall is rated as 0.404 , clay block wall is rated as 0.219 , cement block wall is rated as 0.183 and brick walls is rated as 0.142 are the first, second third and fourth priorities respectively in order to evaluation types of exterior walls to reconstruct Iran earthquake areas (Ahar Heris Varzeqan) and finally, curtain wall rated as 0.141 is the last priority.

As observed, finally, 3D panel wall was selected as the best types of exterior walls in order to reconstruct Iran earthquake areas (Ahar Heris Varzeqan).

\section{FUZZY results}

Fuzzy model of a system is designed based on the previous knowledge of the complete system. Fuzzy logic steps in Figure 3, is divided into four parts:

- fuzzification,

- interference,

- rule base,

- defuzzification.

$\mathrm{X}_{1}, \mathrm{X}_{2}, \mathrm{X}_{3}, \mathrm{X}_{4}, \mathrm{X}_{5}$ are used as fuzzy logic inputs and $A_{1}, A_{2}, A_{3}, A_{4}, A_{5}$ are used as outputs.

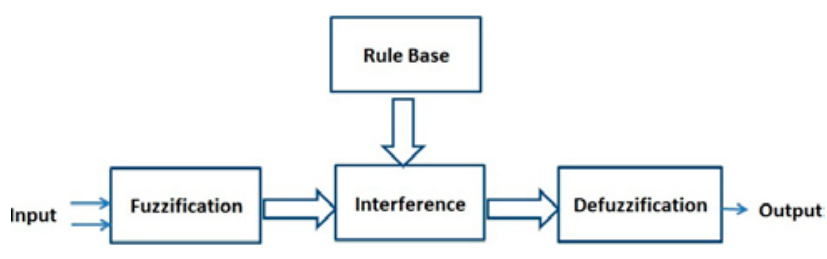

Fig. 3. Fuzzy block

\section{Fuzzification}

A fuzzy-maker is the function which converts numerical data input to the fuzzy data. Fuzzification trend is an important modeling, because these numbers are extended on the model of player and leads the final output. The fuzzification is done by the membership function and it also can be extracted from the introductory knowledge of a system and thereby the use of input data.

\section{Input models}

In this research, the decision criteria's including a collection of Executive and economic characteristics which is to evaluate a variety of external walls of the building in order to rebuild the earthquakestricken areas. Ability to withstand loads resulting from the earthquake, the cost to run, run speed, run complexity and capability of collapse are input models that the type of formation of their preparation function is showed below. The fuzzy membership functions of input factors, shown in Figure 4.

The membership functions of input factors are shown in Figure 4. The implemented logic of fuzzy clustering uses MATLAB software functions. And its membership uses functions of fuzzy inference system of Fuzzy inference system (FIS) editor 


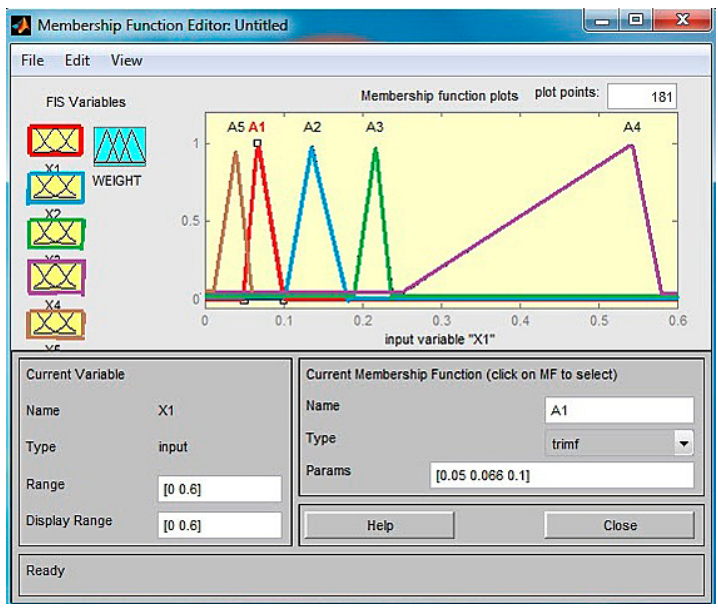

Fig. 4. The fuzzy membership functions of the input factors

available in MATLAB software. Using this editor, we can use the appropriate composition and method of selecting defuzzification method.

\section{Rule base}

In this step, the rules database are created. Interference fuzzy logic without addressing the quality and accurate analysis of a system and only using the conditional rules, which introduced a model which is sufficient for analyzing the quality of the system. In this model, the behavior of the system by the rules "if-then" is described. In the stage of Fuzzy inference through the stage input lingual variables, the rules of the system and membership functions (fuzzy quantities), extract the lingual output variables. The weight of each factor in the research is obtained using AHP method.

Editor FIS, an effective communication tool for implementing graphics designing a user provided with fuzzy logic functions in MATLAB fuzzy logic design for easier production (Table 11).

Table 11. The final weight of inputs and outputs model

\begin{tabular}{lllllll}
\hline \multicolumn{2}{c}{ X1 } & X2 & X3 & X4 & X5 & $\begin{array}{l}\text { Final } \\
\text { weight }\end{array}$ \\
\hline A4 & 0.066 & 0.465 & 0.395 & 0.054 & 0.255 & 0.228 \\
A1 & 0.136 & 0.205 & 0.149 & 0.143 & 0.054 & 0.123 \\
A2 & 0.216 & 0.147 & 0.127 & 0.268 & 0.186 & 0.345 \\
A3 & 0.543 & 0.74 & 0.043 & 0.497 & 0.271 & 0.199 \\
A5 & 0.039 & 0.111 & 0.287 & 0.037 & 0.233 & 0.0619 \\
\hline
\end{tabular}

\section{Interference method}

Fuzzy inference method, specify the output. Mamdani interference method related to methodology is the composition of the Max-Min. because this method is more effective in terms of dynamics and its placement within the characteristics better than others, such as Compositional Rule of Inference (CRI), Generalized Modus Ponens (GMP) and Methods of inference Sugeno. Hence, the inference method for application of engineering is more used (Machado, Rocha 1992).

\section{Defuzzification}

$$
\Delta V_{r e f}=\frac{\int\left(\Delta V_{r e f}\right) \mu_{v}\left(\Delta V_{r e f}\right) d\left(\Delta V_{\text {ref }}\right)}{\int \mu_{v}\left(\Delta V_{r e f}\right) d\left(\Delta V_{r e f}\right)}
$$

Fuzzy output is a Fuzzy set. Hence, the output fuzzy should be defuzzification. Method of Center of gravity is one of the most common defuzzification methods and in this research we also use this method which it is showed in Eq. (5). This method has good characteristics and results show that it has better results (Figs 5, 6, 7, 8, 9).

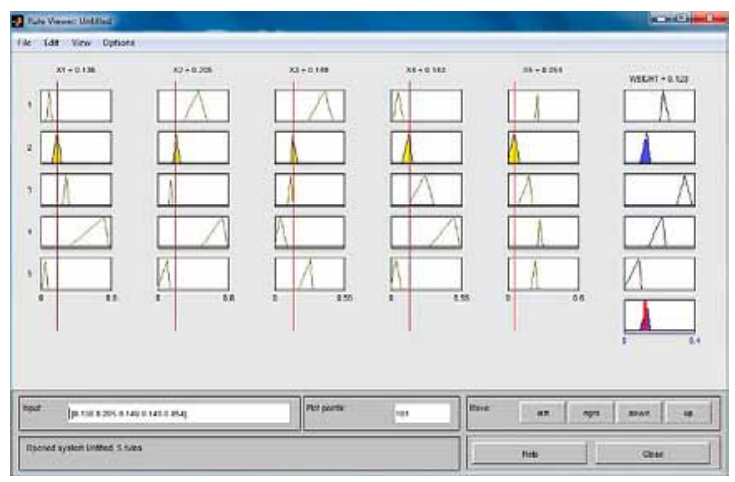

Fig. 5. Output function $A_{1}$

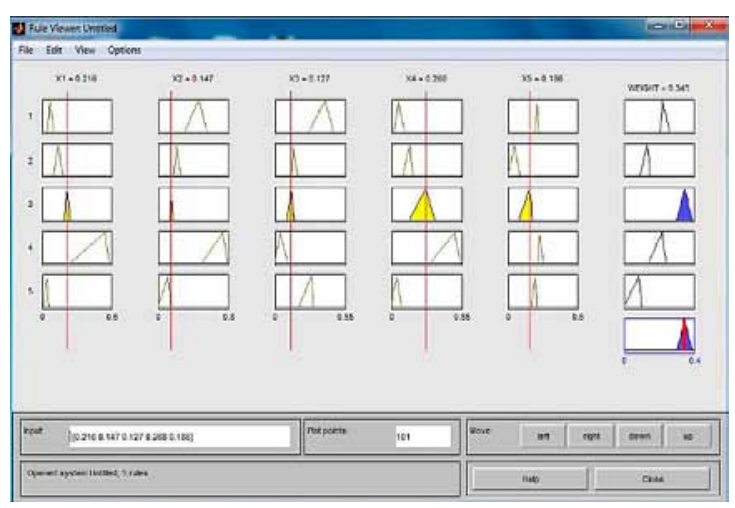

Fig. 6. Output function $\mathrm{A}_{2}$

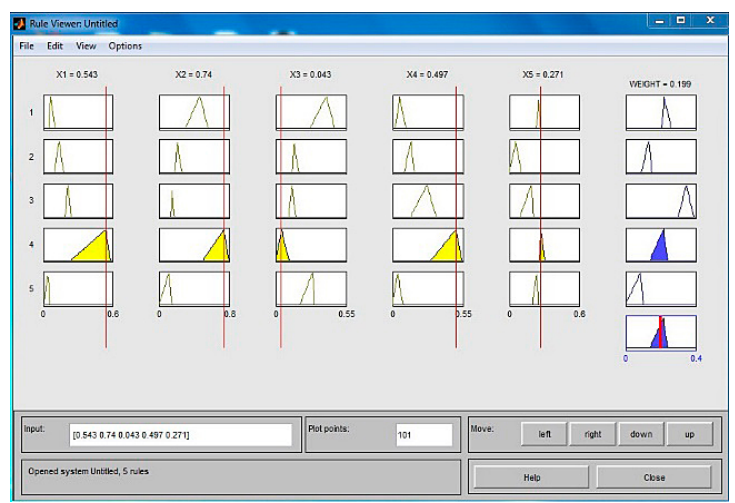

Fig. 7. Output function $\mathrm{A}_{3}$ 


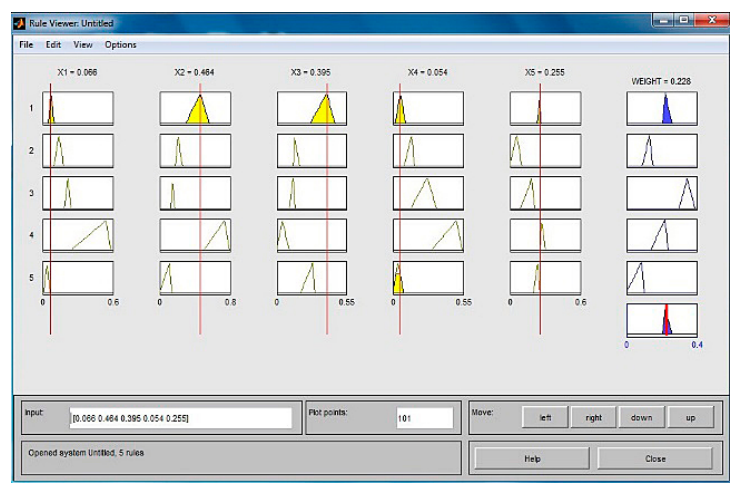

Fig. 8. Output function $\mathrm{A}_{4}$

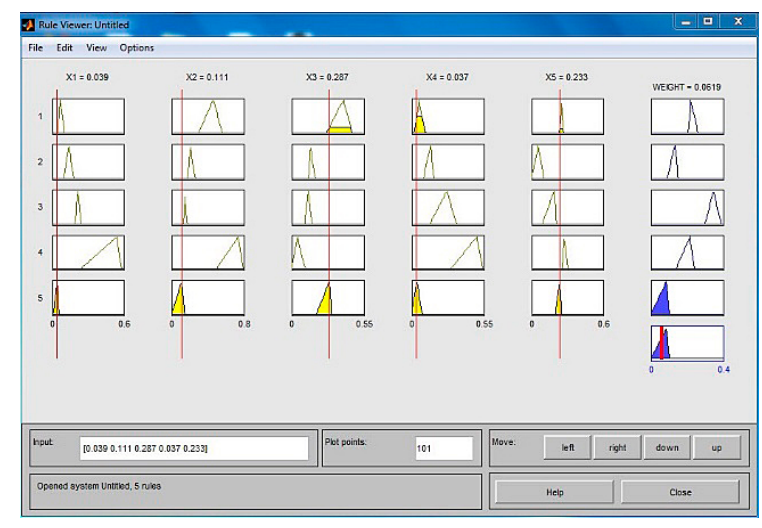

Fig. 9. Output function $\mathrm{A}_{5}$

\section{CONCLUSION}

Based on explorations in earthquake areas (AharHeris-Varzeqan), most of the destruction was due to collapse of exterior walls and debris fall on inhabitants. IN this research all types of exterior walls were studied and the optimal wall was determined based on Delphi method and AHP technique. AHP technique in known as an efficient, low cost and highly accurate in selecting the best option, and as a powerful tool can give you the best option in minimum time and cost. It's obvious that more accurate the data is, more accurate the results will be so, due to accuracy of AHP method, best results are obtainable by asking the experts. to achieve this aim a questionnaire was given to experts of this field. Index of resistance potential against seismic loads is determined as the most critical index based on the analysis of the questionnaire and indices of construction speed, performance cost, debris-removal ability and construction complexity take place after the main index. With the use of mentioned indices the desired exterior wall to renew and reconstruct damaged buildings is $3 \mathrm{D}$ panel wall. The result is high resistance against earthquake force due to high flexibility, high construction speed, low debris-removal ability, ability of industrial manufacture and easy portability. And clay block wall, cement block wall, brick wall and curtain wall take place after 3D panel wall.

This paper presents the comparison of FUZZY and AHP. AHP is already a fuzzy process because most ratios for ranking are not absolute or crisp numbers. In fact, they are already fuzzy numbers and there is no theoretical proof that fuzzifying the comparison data leads to better results therefore it cannot be proved that fuzzifying AHP is a confident idea. The above mentioned statement that AHP is already a fuzzy process is acceptable. Another issue which makes developing a pairwise comparison matrix in the AHP difficult is the fact that the comparison ratios are not exact numbers. It is known that AHP is developed to help decisionmakers to evaluate the importance of some criteria or some alternatives. Mixing concepts of importance and exact numbers is difficult. The numbers $1,3,5,7$ and 9 used in pairwise comparison matrix only indicate the importance of the corresponding factors. The results of the fuzzy are better than AHP results. Because the results of fuzzy can be changed in the MATLAB software environment and the changes are always observable.

\section{REFERENCES}

Akadiri, P. O.; Olomolaiye, P. O.; Chinyio, E. A. 2013. Multi-criteria evaluation model for the selection of sustainable materials for building projects, Automation in Construction 30: 113-125. http://dx.doi.org/10.1016/j.autcon.2012.10.004

Albert, M. L.; Elwi, A. E.; Cheng, J. J. R. 2001. Strengthening of unreinforced masonry walls using FRPs, Journal of Composites for Construction 5(2): 76-84. http://dx.doi.org/10.1061/(ASCE)10900268(2001)5:2(76)

Azari-N, R.; Kim, Y.-W. 2012. Comparative assessment of life cycle impacts of curtain wall mullions, Building and Environment 48: 135-145.

http://dx.doi.org/10.1016/j.buildenv.2011.09.010

Badri M. A. 2001. A combined AHP-GP model for quality control systems, International Journal of Production Economics 72: 27-40. http://dx.doi.org/10.1016/ S0925-5273(00)00077-3

Bagocius, V.; Zavadskas, E. K.; Turskis, Z. 2014. Sequence determining of construction of the offshore wind farm construction applying permutation method, E \& M: Ekonomie a Management 17(3): 50-61. http://dx.doi.org/10.15240/tul/001/2014-3-005

Batayneh, W.; Owais, A.; Nairoukh, M. 2013. An intelligent fuzzy based tracking controller for a dual-axis solar PV system, Automation in Construction 29: 100106. http://dx.doi.org/10.1016/j.autcon.2012.09.006 
Bellman, R. E.; Zadeh L. A. 1977. Local and fuzzy logics, in Dunn, J. M.; Epstein, G. (Eds.). Modern uses of multiple-valued logic, Dordrecht, Netherlands: Reidel, 103-65. http://dx.doi.org/10.1007/978-94-0101161-7_6

Betti, M.; Bartoli, G.; Orlando, M. 2010. Evaluation study on structural fault of a Renaissance Italian palace, Engineering Structures 32(7): 1801-1813. http://dx.doi.org/10.1016/j.engstruct.2010.03.001

Betti, M.; Vignoli, A. 2008a. Assessment of seismic resistance of a basilica-type church under earthquake loading: modelling and analysis, Advances in Engineering Software 39(4): 258-283.

http://dx.doi.org/10.1016/j.advengsoft.2007.01.004

Betti, M.; Vignoli, A. 2008b. Modelling and analysis of a Romanesque church under earthquake loading: assessment of seismic resistance, Engineering Structures 30(2): 352-367. http://dx.doi.org/10.1016/j.engstruct.2007.03.027

Brencich, A. 2010. Deep trench, landslide and effects on the foundations of a residential building: a case study, Engineering Structures 32(7): 1821-1829. http://dx.doi.org/10.1016/j.engstruct.2010.02.019

Calderón, P. A.; Adam, J. M.; Payá-Zaforteza, I. 2009. Failure analysis and remedial measures applied to a RC water tank, Engineering Failure Analysis 16(5): 1674-1685. http://dx.doi.org/10.1016/j.engfailanal.2008.12.004

Ceci, A. M.; Contento, A.; Fanale, L.; Galeota, D.; Gattulli, V.; Lepidi, M. 2009. Structural performance of the historic and modern buildings of the University of L'Aquila during the seismic events of April, Engineering Structures 32(7): 1899-1924.

http://dx.doi.org/10.1016/j.engstruct.2009.12.023

Chai, C.; De Brito, J.; Lima G. P.; Silva, A. 2015. Statistical modelling of the service life prediction of painted surfaces, International Journal of Strategic Property Management 19(2): 173-185. http://dx.doi.org/10.3846/1648715X.2015.1031853

Chou, J.-S.; Anh-Duc, P.; Wang, H. 2013. Bidding strategy to support decision-making by integrating fuzzy AHP and regression-based simulation, Automation in Construction 35: 517-527. http://dx.doi.org/10.1016/j.autcon.2013.06.007

Dağdeviren, M. 2008. Decision making in equipment selection: an integrated approach with AHP and PROMETHEE, Journal of Intelligent Manufacturing 19: 397-406. http://dx.doi.org/10.1007/s10845-008-0091-7

Del Coz Díaz, J. J.; García Nieto, P. J.; Lozano Martínez-Luengas, A.; Suárez Sierra, J. L. 2010. A study of the collapse of a WWII communications antenna using numerical simulations based on design of experiments by FEM, Engineering Structures 32(7): 1792-1800. http://dx.doi.org/10.1016/j.engstruct.2009.09.011

Dubois, D.; Prade, H. 1980. Fuzzy sets systems: theory and applications. Orlando, FL: Academic Press.

Earthquake-Report.com. 2012. Earthquakes Iran (Tabriz, Ahar, Varzghan, Heris area) [online]. Available at: http://earthquake-report.com/2012/08/11/extremely-dangerous-shallow-earthquake-in-the-greater-tabriz-iran-area/ [accessed] include 27/08/2012
Efstathiades, C. H.; Zygomalas, M.; Baniotopoulos, C. C. 2003. Glass-aluminium curtain-wall system: optimization with respect to serviceability criteria, in Proceedings of the $X^{\text {th }}$ international conference on metal structures, oct. 2003, Timisoara, 282-289.

Efstathiades, Ch.; Baniotopoulos, C. C.; Nazark, P.; Ziemianski, L.; Stavroulakis, G. E. 2007. Application of neural networks for the structural health monitoring in curtain-wall systems, Engineering Structures 29: 3475-3484.

Ehasani, M. R.; Saddatmanesh, H.; Velazquez-Dimas, J. I. 1999. Behavior of retrofitted URM walls under simulated earthquake loading, Journal of Composites for Construction 3(3): 134-142. http://dx.doi. org/10.1061/(ASCE)1090-0268(1999)3:3(134)

Ehsani, M. R.; Saadatmanesh, H.; Al-Saidy, A. 1997. Shear behavior of URM retrofitted with FRP overlays, Journal of Composites for Construction 1(1): 17-25. http://dx.doi.org/10.1061/(ASCE)10900268(1997)1:1(17)

Esmaeili, A.; Kahnali, R. A.; Rostamzadeh, R.; Zavadskas, E. K.; Sepahvand, A. 2014. The formulation of organizational strategies through integration of freeman model, SWOT, and fuzzy MCDM methods: a case study of oil industry, Transformations in Business \& Economics 13(3C): 602-627.

Fathy, A. M.; Planas, J.; Sancho, J. M. 2009. A numerical study of masonry cracks, Engineering Failure Analysis 16(2): 675-689. http://dx.doi.org/10.1016/j.engfailanal.2008.02.011

Folic', R.; Zenunovic', D. 2010. Durability problem of RC structures in Tuzla industrial zone - two case studies, Engineering Structures 32(7): 1846-1860. http://dx.doi.org/10.1016/j.engstruct.2010.03.004

Gudiene, N.; Banaitis, A.; Podvezko, V.; Banaitiene, N. 2014. Identification and evaluation of the critical success factors for construction projects in Lithuania: AHP approach, Journal of Civil Engineering and Management 20(3): 350-359. http://dx.doi.org/10.3846/13923730.2014.914082

Hamilton, H. R.; Dolan, C. W. 2001. Flexural capacity of glass FRP strengthened composite masonry walls, Journal of Composites for Construction 5(3): 170-178. http://dx.doi.org/10.1061/(ASCE)10900268(2001)5:3(170)

Işıklar, G.; Büyüközkan, G. 2007. Using a multi-criteria decision making approach to evaluate mobile phone alternatives, Computer Standards \& Interfaces 29: 265-274. http://dx.doi.org/10.1016/j.csi.2006.05.002

Ivorra, S.; Pallarés, F. J.; Adam, J. M.; 2009. Dynamic behaviour of a modern bell tower - a case study, Engineering Structures 31(5): 1085-1092. http://dx.doi.org/10.1016/j.engstruct.2009.01.002

Jato-Espino, D.; Castillo-Lopez, E.; Rodriguez-Hernandez, J.; Canteras-Jordana, J. C. 2014. A review of application of multi-criteria decision making methods in construction, Automation in Construction 45: 151162. http://dx.doi.org/10.1016/j.autcon.2014.05.013

Kang, L.-S.; Kim, S.-K.; Moon, H.-S.; Kim, H.-S. 2013. Development of a $4 \mathrm{D}$ object-based system for visualizing the risk information of construction projects, Automation in Construction 31: 186-203. http://dx.doi.org/10.1016/j.autcon.2012.11.038 
Kaufmann, A.; Gupta, M. M. 1985. Introduction to fuzzy arithmetic, theory and applications. $2^{\text {nd }}$ ed. New York: Van Nostrand Reinhold.

Kaya, I.; Kahraman, C. 2014. A comparison of fuzzy multicriteria decision making methods for intelligent building assessment, Journal of Civil Engineering and Management 20(1): 59-69.

http://dx.doi.org/10.3846/13923730.2013.801906

Keršulienè, V.; Turskis, Z. 2014. A hybrid linguistic fuzzy multiple criteria group selection of a chief accounting offices, Journal of Business Economics and Management 15(2): 232-252.

http://dx.doi.org/10.3846/16111699.2014.903201

Kildienè, S.; Zavadskas, E. K.; Tamošaitienè, J. 2014. Complex assessment model for advanced technology deployment, Journal of Civil Engineering and Management 20(2): 280-290. http://dx.doi.org/10.3846/13 923730.2014 .904813

Korany, Y.; Drysdale, R. 2006. Rehabilitation of masonry walls using unobtrusive FRP techniques for enhanced out-of-plane seismic resistance, Journal of Composites for Construction 10(3): 213-222. http:// dx.doi.org/10.1061/(ASCE)1090-0268(2006)10:3(213)

Kriksciuniene, D.; Sakalauskas, V.; Strigunaite, S.; Masteika, S. 2015. Project performance evaluation by modified analytic hierarchy process model, Transformations in Business \& Economics 14(1): 192-211.

Kutut, V.; Zavadskas, E. K.; Lazauskas, M. 2014. Assessment of priority alternatives for preservation of historic buildings using model based on ARAS and AHP methods, Archives of Civil and Mechanical Engineering 14(2): 287-294.

http://dx.doi.org/10.1016/j.acme.2013.10.007

Kwon, O. S.; Kim, E. 2010. Case study: analytical investigation on the failure of a two-story RC building damaged during the 2007 Pisco-Chincha earthquake, Engineering Structures 32(7): 1876-1887. http://dx.doi.org/10.1016/j.engstruct.2009.12.022

Lakhmi, C. J.; Martin, N. M. 1998. Fusion of neural networks, fuzzy systems and genetic algorithms: industrial applications. Boca Raton, FL: CRC Press LLC.

Lee, W. F.; Ishihara, K. 2010. Forensic diagnosis of a shield tunnel failure, Engineering Structures 32(7): 1830-1837. http://dx.doi.org/10.1016/j.engstruct.2010.03.012

Li, T. H. Y.; Ng, S. T.; Skitmore, M. 2013. Evaluating stakeholder satisfaction during public participation in major infrastructure and construction projects: a fuzzy approach, Automation in Construction 29: 123135. http://dx.doi.org/10.1016/j.autcon.2012.09.007

Lourenço, P. B.; Krakowiak, K. J.; Fernandez, F. M.; Ramos, L. F. 2007. Failure analysis of Monastery of Jerónimos, Lisbon: how to learn from sophisticated numerical models, Engineering Failure Analysis 14(2): 280-300.

http://dx.doi.org/10.1016/j.engfailanal.2006.02.002

Machado, R. J.; Rocha, A. F. 1992. Hybrid architecture for fuzzy connectionist expert systems, in Kandel, A.; Langholz, G. (Eds.). Hybrid architectures for intelligent systems. Boca Raton, FL: CRC Press.

Medineckiene, M.; Zavadskas, E. K.; Bjork, F.; Turskis, Z. 2015. Multi-criteria decision-making system for sustainable building assessment/certification, $A r$ chives of Civil and Mechanical Engineering 15(1): 11-18. http://dx.doi.org/10.1016/j.acme.2014.09.001

Nassar, K.; Hosny, O. 2013. Fuzzy clustering validity for contractor performance evaluation: application to UAE contractors, Automation in Construction 31: 158-168.

Numayr, K. S.; Al Rjoub, Y. S.; Qudah, A. M.; AlDeen, K.; Bsisu, I. 2012. Resistance of exterior threedimensional walls to high velocity projectiles, Composites: Part B 43: 3431-3435.

http://dx.doi.org/10.1016/j.compositesb.2012.01.027

Robert, F. 1995. Neural fuzzy systems. Abo Akademi University.

Saaty, L. T. 1980. The analytic hierarchy process. New York: McGraw Hill Company.

Sasaki, K. K.; Paret, T.; Araiza, J. C.; Hals, P. 2010. Failure of concrete T-beam and box-girder highway bridges subjected to cyclic loading from traffic, Engineering Structures 32(7): 1838-1845.

http://dx.doi.org/10.1016/j.engstruct.2010.01.006

Shi, S.-S.; Li, S.-C.; Li, L.-P.; Zhou, Z.-Q.; Wang, J. 2014. Advance optimized classification and application of surrounding rock based on fuzzy analytic hierarchy process and Tunnel Seismic Prediction, Automation in Construction 37: 217-222. http://dx.doi. org/10.1016/j.autcon.2013.08.019

Simanaviciene, R.; Liaudanskiene, R.; Ustinovichius, L. 2014. Assessing reliability of design, construction, and safety related decisions, Automation in Construction 39: 47-58. http://dx.doi.org/10.1016/j.autcon.2013.11.008

Šiožinytė, E.; Antuchevičienè, J.; Kutut, V. 2014. Upgrading the old vernacular building to contemporary norms: multiple criteria approach, Journal of Civil Engineering and Management 20(2): 291-298. http://dx.doi.org/10.3846/13923730.2014.904814

Sivilevicius, H.; Maskeliunaite, L. 2014. The numerical example for evaluating the criteria describing the quality of the trip by international train, $E \& M$ : Ekonomie a Management 17(2): 73-86. http://dx.doi.org/10.15240/tul/001/2014-2-006

Tiago, P.; Júlio, E. 2010. Case study: damage of an RC building after a landslide - inspection, analysis and retrofitting, Engineering Structures 32(7): 1814-1820. http://dx.doi.org/10.1016/j.engstruct.2010.02.018

Triantafillou, T. C. 1998. Strengthening of masonry structures using epoxy bonded FRP laminated, Journal of Composites for Construction 2(2): 107-115. http:// dx.doi.org/10.1061/(ASCE)1090-0268(1998)2:2(96)

Vodopivec, B.; Žarnić, R.; Tamošaitienè, J.; Lazauskas, M.; Šelih, J. 2014. Renovation priority ranking by multi-criteria assessment of architectural heritage: the case of castles, International Journal of Strategic Property Management 18(1): 88-100. http://dx.doi.org/10.3846/1648715X.2014.889771

Wang, J. J.; Yang, D. L. 2007. Using a hybrid multi-criteria decision aid method for information systems outsourcing, Computers \& Operation Research 34: 36913700. http://dx.doi.org/10.1016/j.cor.2006.01.017

Willis, C. R.; Yang, Q.; Seracino, R.; Griffith, M. C. 2009. Damaged masonry walls in two-way bending retrofit- 
ted with vertical FRP strips, Construction and Building Materials 23(4): 1591-1604.

http://dx.doi.org/10.1016/j.conbuildmat.2007.09.007

Yazdani-Chamzini, A.; Razani, M.; Yakhchali, S. H.; Zavadskas, E. K.; Turskis, Z. 2013. Developing a fuzzy model based on subtractive clustering for road header performance prediction, Automation in Construction 35: 111-120.

http://dx.doi.org/10.1016/j.autcon.2013.04.001

Yazdani-Chamzini, A. 2014a. An integrated fuzzy multi criteria group decision making model for handling equipment selection, Journal of Civil Engineering and Management 20(5): 660-673.

http://dx.doi.org/10.3846/13923730.2013.802714

Yazdani-Chamzini, A. 2014b. Proposing a new methodology based on fuzzy logic for tunnelling risk assessment, Journal of Civil Engineering and Management 20(1): 82-94.

http://dx.doi.org/10.3846/13923730.2013.843583
Yazdani-Chamzini, A.; Shariati, S.; Yakhchali, S-H.; Zavadskas, E. K. 2014. Proposing a new methodology for prioritising the investment strategies in the private sector of Iran, Economic Research-Ekonomska Istrazivanja 27(1): 320-345.

http://dx.doi.org/10.1080/1331677X.2014.947150

Zadeh, L. A. 1972. A fuzzy-set-theoretic interpretation of linguistic hedges, Journal of Cybernetics 2: 4-34. http://dx.doi.org/10.1080/01969727208542910

Zadeh, L. A. 1973. Outline of a new approach to the analysis of complex systems and decision processes, IEEE Transactions on Systems, Man, and Cybernetics 3: 28-44. http://dx.doi.org/10.1109/TSMC.1973.5408575

Zavadskas, E. K.; Turskis, Z.; Bagocius, V. 2015. Multicriteria selection of a deep-water port in the Eastern Baltic Sea, Applied Soft Computing 26: 180-192. http://dx.doi.org/10.1016/j.asoc.2014.09.019 